\title{
The implementation of social customer relationship management for tourism information system
}

\author{
Ali Ibrahim ${ }^{1}$, Dwi Rosa Indah ${ }^{2}$, Devi Indra Meytri ${ }^{3}$ \\ ${ }^{1,2,3}$ Department of Information Systems, Faculty of Computer Science, Universitas Sriwijaya, Ogan Ilir, Indonesia \\ ${ }^{1}$ Management of Information Systems and Business (MISaB) Research Group, Faculty of Computer Science, \\ Universitas Sriwijaya, Ogan Ilir, Indonesia. \\ ${ }^{1}$ Multimedia and Game Programming Laboratory, Faculty of Computer Science, Universitas Sriwijaya, Ogan Ilir, \\ Indonesia \\ ${ }^{2}$ Data structures and accounting information systems Laboratory, Faculty of Computer Science, Universitas Sriwijaya, \\ Ogan Ilir, Indonesia
}

\begin{tabular}{|c|c|}
\hline Article Info & ABSTRACT \\
\hline Article history: & \multirow{10}{*}{$\begin{array}{l}\text { Semambu island village, Ogan Ilir regency, south Sumatra has been used as } \\
\text { an agricultural and livestock education tour destination since November } 2017 \\
\text { and there has been no customer data management since then. The use of } \\
\text { social media as a promotional tool has not been done to its maximum } \\
\text { potential. This can be seen from } 189 \text { people who liked its Facebook page or } \\
11.05 \% \text { out of the reached users, } 192 \text { followers or } 11.23 \% \text { and those who } \\
\text { interacted as many as } 114 \text { people or } 6.67 \% \text { from the total users. Meanwhile, } \\
\text { there were } 709 \text { followers on its Instagram which consisted of } 48 \% \text { men and } \\
52 \% \text { women at the time of the study. This research applied social customer } \\
\text { relationship management (social CRM) in a website-based system. The } \\
\text { waterfall model development method supported the customer relations } \\
\text { management by utilizing Facebook and Instagram to improve customer } \\
\text { relationships in providing travel information, knowing interest and listening } \\
\text { to complains as well as their suggestions based on interactions with the social } \\
\text { media users as existing and prospective customers. }\end{array}$} \\
\hline Received Feb 8, 2021 & \\
\hline Revised Oct 27, 2021 & \\
\hline Accepted Nov 1, 2021 & \\
\hline Keywords: & \\
\hline Customers & \\
\hline Facebook & \\
\hline Instagram & \\
\hline Social CRM & \\
\hline Village tourism & \\
\hline
\end{tabular}

This is an open access article under the CC BY-SA license.

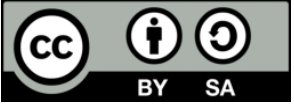

\section{Corresponding Author:}

Ali Ibrahim

Department of Information Systems, Faculty of Computer Science

Universitas Sriwijaya

Ogan Ilir Regency, South Sumatra 30862, Indonesia

Email: aliibrahim@unsri.ac.id

\section{INTRODUCTION}

In Ogan Ilir regency, there is a village called Semambu island, where the majority of the residents are farmers and breeders. There was an idea from the juveniles to make the village as a tourist attraction based on agriculture and animal husbandry education by following the daily activities of the farmers. The main target of visitors are urban communities without age restrictions who do not have experience in agriculture and animal husbandry. They can range from students on field trips, company family gathering members to families with a minimum of 10 people per group visit. This tour attracts visitors because there is no educational tour like this in south Sumatra, with easy access to the location via Palembang-Indralaya toll road hence making the journey from Palembang can be reached within 30 minutes, not to mention the tour guides who have experience in agriculture. The initial promotional activity undertaken by the manager was distributing proposals and brochures to schools in Palembang and southern Sumatra. Promotion with printed media such as banners and tourism board signs is not yet done. On the other hand, the use of information 
technology has been used for booking and marketing process of this tour through social media such as Instagram, Facebook and Whatsapp. This shows that the management has realized the benefits of using social media in disseminating information about this tour, where visitors who come usually provide recommendations to the public through their personal social media accounts. There is no storage and management of customer data, such as the use of Facebook and Instagram by uploading photos and videos of visitors activity. Complaints and suggestions from them are directly delivered when the activity has finished. But the management using social media just for share information without any purpose to get more advantage of social media.

The business process of a tourist attraction is closely related to people's interest in order to increase the number of visitors, so special strategies for a tourist attraction in order to survive in the era of global competition like today are needed. Business activities which are conducted electronically require customers as the source of company revenue. The existence of customers today is not only as the source of company revenue, but also a long-term asset that needs to be managed and maintained through customer relationship management (CRM) [1]. The quality of human resources and technology is crucial for maintaining customers by building a long-term relationship with existing customers that will increase profits for the company [2]. Changes in technology are currently shifting our point of view, behavior and communication in social activities so that a special way is needed to utilize technology in maintaining relationships with customers [3].

Social customer relationship management (social CRM) is a business strategy that is supported by electronic platform and social characteristics to provide benefits to the business environment [4]. Social CRM is the development of traditional CRM related to how to include customers which is often referred to as customer engagement [5], where there are differences on the way customer data is managed and active participation through various social media can contribute to improving the quality and adaptation of products according to the customers wish and needs [6]. The first CRM application was customer information system (CIS) in 1980 which served to assist the specific work of employees. It was then developed into electronic CRM (E-CRM) that utilized the internet. The application was in the form of websites, forums and e-mails to achieve CRM goals. The challenge of E-CRM was that it needed interesting topics for customers to start a communication to generate information. On social CRM, a business entity creates fan pages on social media sites to get information about users who are interested in offered products quickly [7]. Social CRM is a transformation from traditional CRM where initially information in the form of data collection of customer characteristics obtained from past behavior was stored in the data warehouse. It was then analyzed to get the possibility of future behavior, which would be obtained from interaction through social media so that the process of documenting customer information was done quickly. Establishing close relationships with customers and marketing activities would be more efficient because they knew what the customers wanted and needed through their active participation in collaborative discussions [8]. Many companies collect the number of community members (commonly called fans, friends, followers or people who like the post). Social CRM is closely related to the behavior performed by the customer (social network users) [9]. With the emergence of social web, it can be used to depict graphics and extracts of social analysis reports with the aim to understand market trends and behavior such as opinions about products, what the customers want and their preferences [10]. The application of social CRM is, it is integrated with an organization's social media so that automatic interaction occurs with fans, followers, customers or people who like the page so that it finds out how market responses towards the products or services provided to be able to respond directly, or forward the information to more interested parties [11].

A successful CRM strategy has three basic fundamentals. First "who your customers are". The company understands well the types of relationships that must be built with customers. Second "how both parties obtain value from the relationship", which means that it must be ensured that customers and companies benefit each other. Third "systems and software are only as effective as the strategy behind them". The company focuses on improving customer relationships through good communication [4]. By implementing CRM can be used as a benchmark to improve services to users [12]. Social CRM approach uses social media to determine customer needs from information obtained through social interactions. There are four dimensions of the information relations process, namely capturing information through different social media user submissions, information integration through interaction to conclude how relationships should be established with customers, access and use of information for decision makers in marketing to be used to get acquire, and enhancing and retaining the customer [13]. The data is obtained and analyzed from social media or website-based application. Social CRM is expected to be implemented with customer engagement and social media technology to increase customer trust and loyalty [4]. Besides that the promotion of using social media provides an advantage in the expenditure sector and the use of social media to market products and services is very easy to understand [14]. The process of getting new customers can be done through promoting through social media such as advertising on Youtube, Facebook page or provide product/service information at Wikipedia and provide attractive offers for new customers [15]. Increasing 
customer value can be done by creating groups or communities on social media specifically for customers to continue to communicate with other customers, give pride as part of a brand and make customers as members to get a variety of special services [16].

Created system could improve services to customers [17]. Meanwhile, retaining customers can be done by contacting them personally such as sending product catalogue emails to those who have bought the product [15], finding out the customer's response to social media posts through the number of likes, commenting or spreading the post to their social media friends [18], and responding to their comments. When there are negative comments, personal approach can be done to follow up their bad experiences which made them post negative comments [16]. By implementing SCRM in the service and marketing process, it can bring good relations between consumers and owner of as well as it can increase customer satisfaction and loyalty [19]. Using social media is good for measuring customer satisfaction as well because it provides by the application. Measure customer relationship management provide future evaluation for the Faculty of Computer Science, Universitas Sriwijaya (Fasilkom Unsri) canteen in managing the customer [20].

The company requires the following aspects to utilize social media with CRM. They should be aware of the power of social media. They should clearly distinguish the difference between social media and the other media, create customer experiences through them, start things based on the customer's views, ask their expectations through interaction, and utilize big data to benefit from the social media [21]. The application of social CRM by utilizing social media and websites used to disseminate tourism information in Semambu island village, obtained customer information by storing booking data, and finding out potential customers' interest in Semambu island through Facebook information analysis and Instagram which was expected to increase the number of tourists, find out potential customers' interests and build better relationships with them.

\section{METHOD}

The research about the use of social CRM as a business strategy stated that utilizing CRM and social media could provide financial benefits to the company. The benefits in the process of obtaining, maintaining, increasing value and managing expenses is needed in maintaining relationships with customers. This social CRM project is not just about systems. Technology is important for analyzing and mapping data. Social CRM is about people and relationships that focus on every customer [22].

The emergence of social web meant a source of new information and as a medium of communication for individuals. Then business people realized that social web is a word-of-mouth marketing with a low cost and it can be used to reach marketing targets through the community. There is an opportunity to get new markets related to market participants and people can interact with their customers personally using simple media [23]. Social capital is present when there is trust and loyalty among the users [24]. Meanwhile, according to the researches related to social CRM as a whole is a concept of strategy that is still developing, which is undeniably still considered the same as the CRM domain. Practitioners unfamiliarity in implementing and operating social CRM programs at the overall level prevents social CRM domain development to become part of the relevant scientific literature [25]. Apart from that, there are various benefits derived from the use of social media in the world of CRM, ranging from the cost efficiency needed to carry out promotions, and the ability to reach many prospective customers. In addition, there are users who can be segmented based on age, gender, location of residence and even their interest. Lastly, it's the ability to strengthen relationships between customers with the company by establishing intensive communication and making customers active participants not just as viewers to then get detailed information about them [7].

Social media is a key that allows companies to get customer data and increase customer knowledge which can also be used to increase competitive power especially to improve the relationships with customer [26]. Social media is an area that everyone can access in real time. So, a company must continue to communicate with its customers to get responses to products or services to strengthen the company's value and position [27]. In a study about the effectiveness of using Facebook as marketing media, further research was suggested for using various social media to find out their effectiveness in terms of the messages frequency that should be sent and how they differ from traditional marketing [28]. Social media has a positive impact on marketing because it is a marketing tool that can be used to interact with new customers and retain old customers [29]. However, unstructured data management is needed from the corporate and its environment, for example the data from social networks [30].

The shift from traditional CRM into social CRM also requires a clear view of how to engage customers and implement social media marketing strategies because social media users are critical, easy to spread news and if companies are not careful, it will backfire their performance and development [31]. The use of social media in CRM has a positive impact because social media is the main place for people to give their opinions, or at least have a great influence on public opinion. Social media which is used to convey 
information also controls and directs public opinion. A company can get important information about customer satisfaction that is more difficult to obtain using traditional way [22]. Allowing the customers to interact with customer service that company has provided to keep track of the satisfaction [32]. The marketing department and manager must be able to segment customers using social media based on unique differences in order to increase communication efficiency when doing marketing. The things that can be done to get closer to customers is to immediately respond to their questions and suggestions, but to be closer to customers, companies can also like, or respond to customer's submissions on their social media accounts with messages that remain related [33].

Social media is an ideal tool to inspire, identify and interact with customers through a brand. Building a good image of a brand can be done by taking advantage of the transparency of social media data, for example by displaying honest responses from customers [13]. But, fully reading reviews is quite difficult [34]. To increase popularity, a social media is needed, but high popularity must be in line with good operational performance [35]. Almost all studies on information technology productivity and it role for companies performance are based on data collected and meta-analysis and do not offer a methodology or prototype of analysis in any field [36]. Enabling businesses to collect and analyse customer feedback to make business decisions to be more advanced in the future [37]. Majority of the respondents agreed that expert system as tool for conversational booking based on pattern matching stands at an unbiased state while being more aligned on supporting the usefulness of the system to enhance tourism [38].

A lot of researches on social CRM model basically used the theories and concepts of traditional CRM with various innovations but were still limited to the concept and what remained to be done was how social media could be used as a CRM development media. Social CRM can increase customers satisfaction and loyalty through interaction with the other customers rather than just managing them using social media which is the most important part because it is accepted and used widely by customers [3]. CRM factors included the gathering of information, the processing of data, the management of information, the loyalty of customers, and the retention of customers with significantly related to the performance of a firm [39]. Integrated data will support the company in interacting with customers inside social CRM in an environment built to ensure the creation of customer relationship management [40]. Social media began to exist in the late 1970s when Tom Truscott and Jim Ellis discovered Usenet which allowed internet users to send messages to the public. The effectiveness of promotion using social media, it was concluded that social media became an effective media as a communication tool to carry out marketing strategies. Easy-to-reach social media accounts can build two-way communication relationships so that customers feel closer to the brand and allow ongoing interaction with customers from all over the world [41].

Social media is a new revolutionary tool that enables communication between individuals, companies and different groups from all over the world to share and exchange information and ideas in an interactive way. There are various types of social media, such as social networks (Facebook, Instagram, Twitter and LinkedIn), blogs, forums, multimedia content sharing platforms such as Youtube, or collaboration like Yahoo answer [8]. Based on the data from the website wearesocial.com, until July 2018 more than 4.1 billion people were connected online or $54 \%$ of the total internet users in the world. Similarly, social media users are increasing by $11 \%$ every year. There are 328 million new users to social media a year or almost 1 million a day. Up to July 2018 social media users had reached 3.3 billion and $92 \%$ of them accessed it through their mobile device. Alexa Global Website Ranking in July 2018 conducted a website ranking survey based on the most accessed page that can be seen on Figure 1. There are 20 highest with different purpose websites. For social media, the results showed that Facebook ranked the third and Twitter on the 10th place, meanwhile Instagram ranked the 13th.

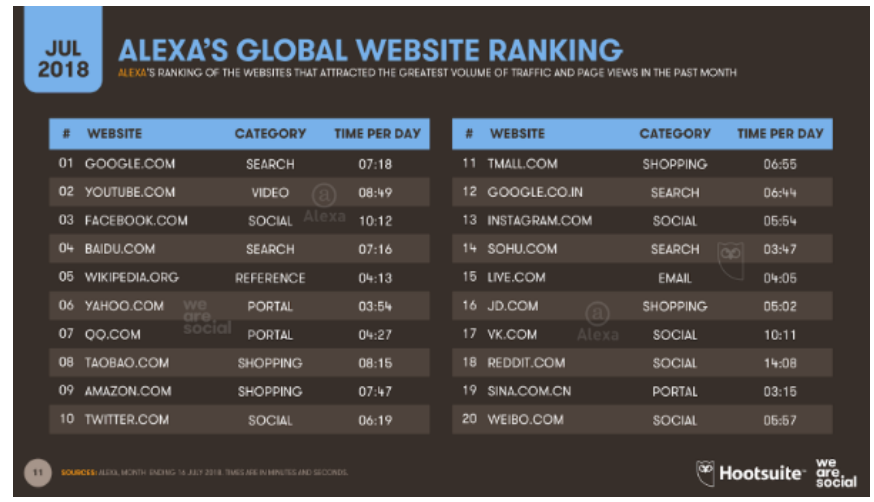

Figure 1. World website rank per July 2018 
Social media which is universal affects marketing process because customers can among them to exchange information which means the marketing process happens within their communication [42]. Marketing using social media is also called word-of-mouth marketing or viral marketing because it is a social network that can be used by many people and it can spread information through group discussions, posts, comments from someone's posts, ratings and other interactions [7]. Mercedes-Benz was able to increase its number of website visitors as much as $580 \%$ after using Instagram and Facebook as their promotional media [42]. This study used Facebook and Instagram because Facebook is the most suitable media used for promotional media since there is no limit to the amount of information that can be shared unlike Instagram or Twitter. It can share various types of information not limited to videos such as Youtube. The users are not limited to a circle such as LinkedIn for professionals. It does not only contain personal opinions as blogs. Every user can communicate each other easily unlike social media-based messaging applications such as Whatsapp and Line. In addition, it is not dominated by any gender and not restricted with interests such as Pinterest. Other than that, Facebook is a social media that provides advertising features so that market segmentation is possible to effectively do the promotion aimed to meet the customers needs according to the products or offered services.

Other digital innovations are needed for customers alternatives to interact with. They are also needed to share products, stores and information that are distributed [11]. A case study of three companies that used social media conducted by Paliouras and Siakas in 2017 showed that these companies benefited from increasing customers by utilizing free of charge, free to use and viral features of social media that could significantly have a good impact through increasing brand awareness, popularity and customer trust that can ultimately increase the customers' number. Meanwhile, the drawback was the amount of time needed to monitor the data from a variety of different social networks [7].

Social CRM could be a dynamic characteristic in small and medium-sized enterprises (SMEs), and was recommended because it could automate and enable the collection and integration of social media data that can make small and medium-sized companies benefit more than resources and limitations in the long term [43]. The highest impact on recovery satisfaction comes from perceived trust as the initial predictor to use the service [44]. Social CRM capability has become very important when a company uses social media as a marketing strategy to increase customer interest and company performance [45] because it can be utilized in companies marketing by planning, conducting and evaluating customer responses to promotional activities through direct interaction with customers through social media [8].

The measurement of social CRM utilization results is useful for controlling its system activity as it shows which social media are effective and which ones are less effective, allowing companies to find out current and future social CRM. Operational measurements are able to compare efforts with competitors and companies can clearly set goals such as interacting on social media with more than $10 \%$ of their customers [46]. CRM means understanding people's behavior and interests, who make use of big data to better know customers personally because they can segment potential customers [42].

\subsection{Data collection methods}

Data collection methods are:

- Interview: The researchers conducted an interview with the head of Semambu island tourism village Management Team, Mr. Kodrat Puja Kesuma, S.TP to find out the needs of the system to be designed.

- Literature Review: This was done by browsing library resources related to research including books, journals, articles, theses and dissertations.

- Observation: The researchers made direct observations on the object of research, the tourist sites and Facebook and Instagram social media of Pulau Semambu village.

Systems development method: this study used structural design that is focused more on the data. Web based social CRM system that utilize Facebook and Instagram was developed using Waterfall model which is one of system development methods using structured approach on software developement life cycle (SDLC) [47]. Social CRM approach at the analysiss phase of SDLC because at this phase who will use and what will be done by the system defined. To get a clear picture, the research framework can be seen in Figure 2.

The problem with the system development method was that the client requested changes after the system development was completed so that it became a problem for the development team. However, this could be overcome by running the standard. Waterfall standard model is assuming a great decision which was taken before starting the coding process until the increase of development costs according to the phase [48]. The things that must be considered in CRM implementation are challenges [42]. The challenges of CRM were lack of support from management, unclear vision and strategy, poor change management, poor training programs, lack of customer orientation and poor human resource skills [4].

There are 3 types of social media users, as follows [41]: 
- Active, i.e. users who follow social media and see information shared by a brand's social media account.

- Half active, i.e. users who do not follow a brand's social media account but have visited some social media accounts to get information. This type of user is interested but doesn't want to get information about the brand regularly.

- Passive, i.e. users who don't follow and visit social media but have the potential to become customers because they just don't want to be too attached to a brand.

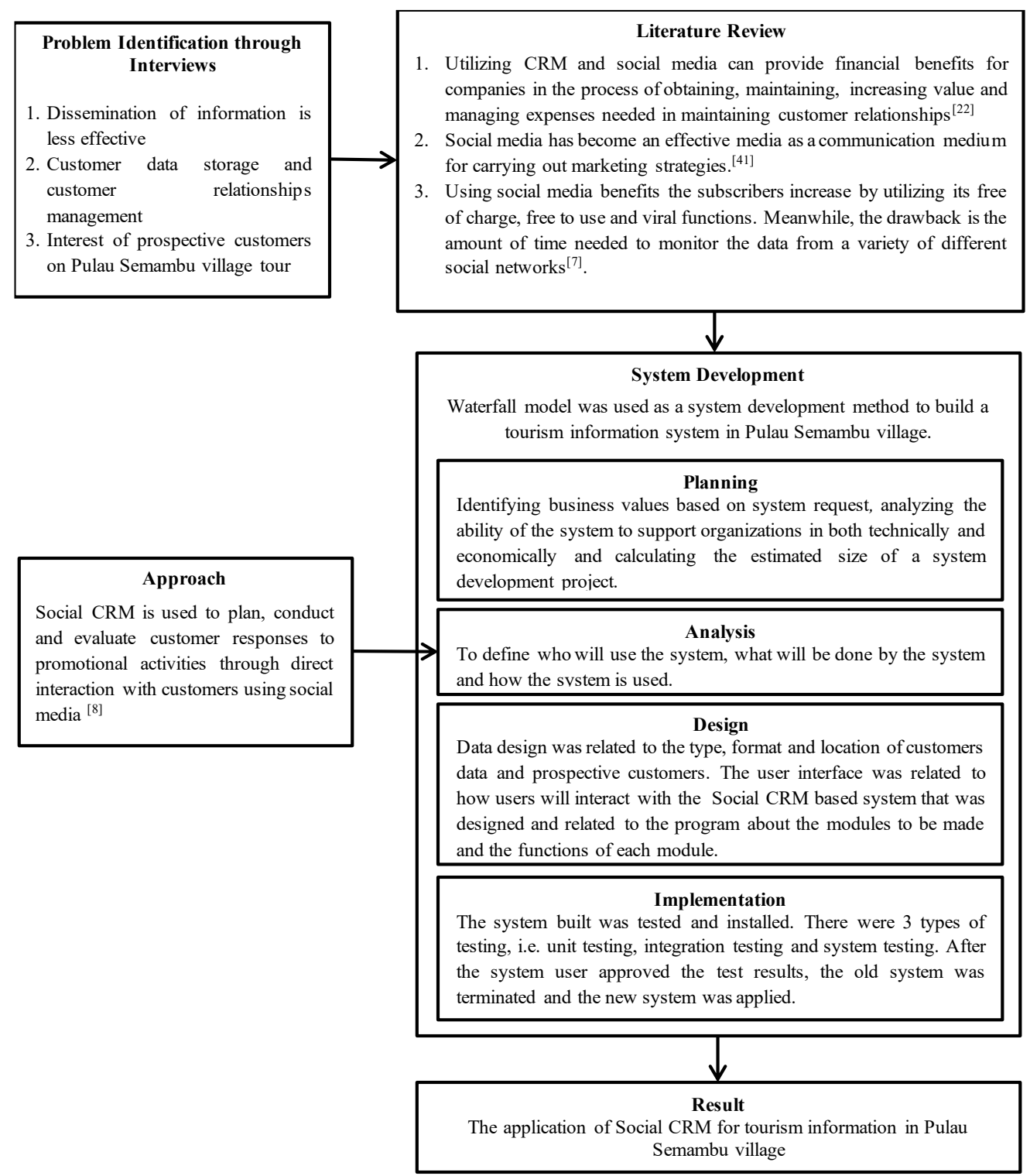

Figure 2. Research framework

Passive social media users can still receive information about a brand through posts that their friends like, comment on or share. This makes the promotion carried out through social media effective and efficient because it is able to reach potential customers and always build good relationships with existing customers. Social media is currently a factor that determines the customer's decision to buy a product by finding information related to that product [8].

In a study [41], only $31.5 \%$ of research respondents were followers the research object's brand social media. This is a low number, but actually some respondents often visited the brand's social media and did not become followers because they did not want to accept any spam. The level of accuracy of classification of consumer ratings is still not optimal because the weight of values in the data preprocessing process are not optimal [49]. So, with the development of technology and high competition CRM is used to survive the intense competition [50]. 


\section{RESULTS AND DISCUSSION}

There were two main problems that existed in Pulau Semambu island village; ineffective information dissemination and the information that had been spread as well as customer data was not stored. As a solution, a system with several functional requirements was designed as follows:

- The system can send information through the website and social media.

- The system can retrieve customer data that is useful for managing their relationships through the customer data collection process.

- The system can store visit data and generate visit reports.

- The system can provide information dissemination analysis.

The system had 5 main processes. The first was to manage the management team data as a system user, available tour packages and tourist information. The second process was sharing information which the manager spread through the website and social media, then getting responses from social media users which were then analyzed and for further information dissemination. The third process was booking a tour package through the website conducted by potential visitors so that their data could be stored. The fourth process was improving customer relationships through the delivery of complains and suggestions as well as marketing email delivery to customers. The fifth process was making the visit report forwarded to the head of the management team. The system was implemented in a website using hypertext preprocessor (PHP) language and hypertext markup language (HTML) display using Indonesian language. Figure 3 as shows screenshot of the website that display button to share the information through the social media.

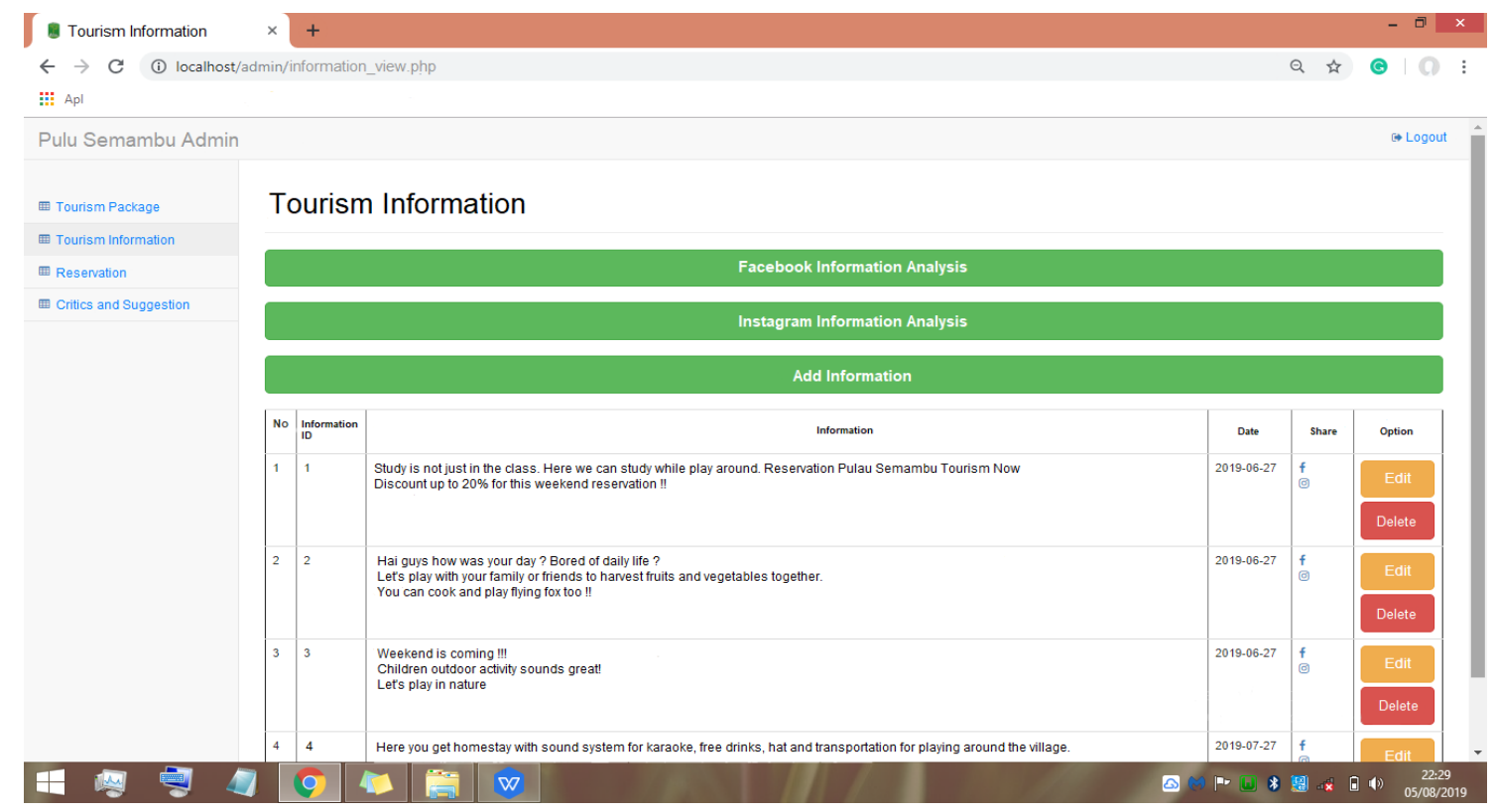

Figure 3. Spread information through the website and social media

Information sharing through website and social media makes travel information not only spread but also stored, can be accessed at any time and can be analyzed to be a consideration for the dissemination of further information about the type of information which is of interest to social media users as customers and prospective customers, the right time of dissemination and the interested social media users. Instagram page analysis was used to find out the interests of potential customers through the Instagram users' response on the page and posts. Analysis of tourism information dissemination was also done through Instagram as in Figure 4 to find out potential Instagram customers' interests and user responses to the given information which was useful for the next information dissemination. The following pictures are screenshots of the information analysis for Instagram.

Meanwhile Facebook page analysis as in Figure 5 was used to find out the interests of potential customers through the Facebook users' response on the page and posts. Information are people who interest with Semambu island tourism village page in Facebook. The following pictures are screenshots of the information analysis for Facebook. 


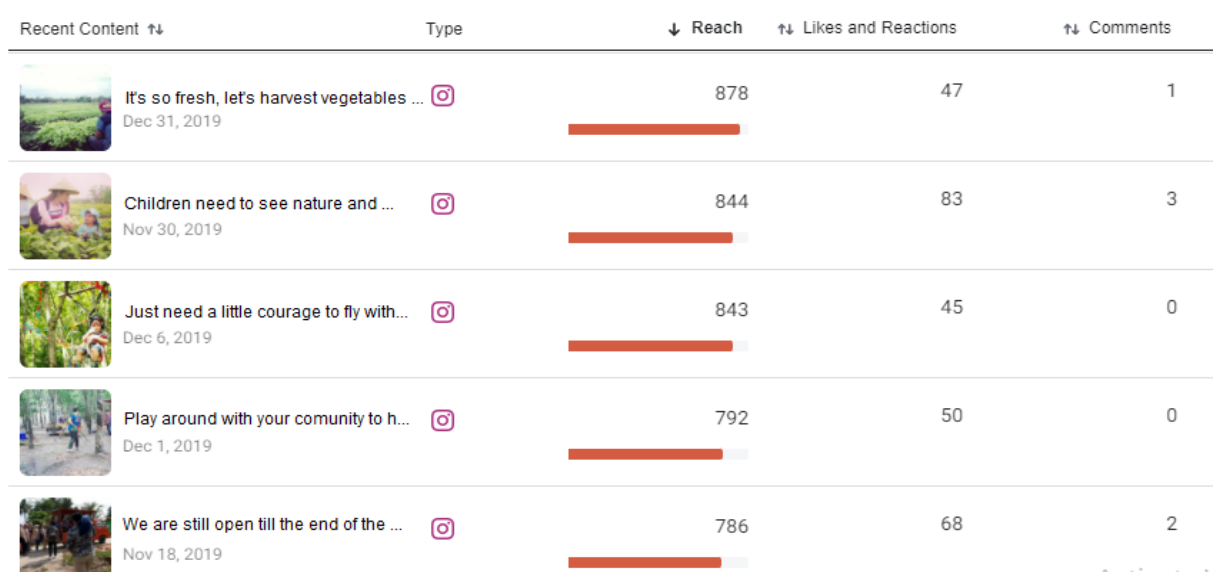

Figure 4. Information analysis on Instagram

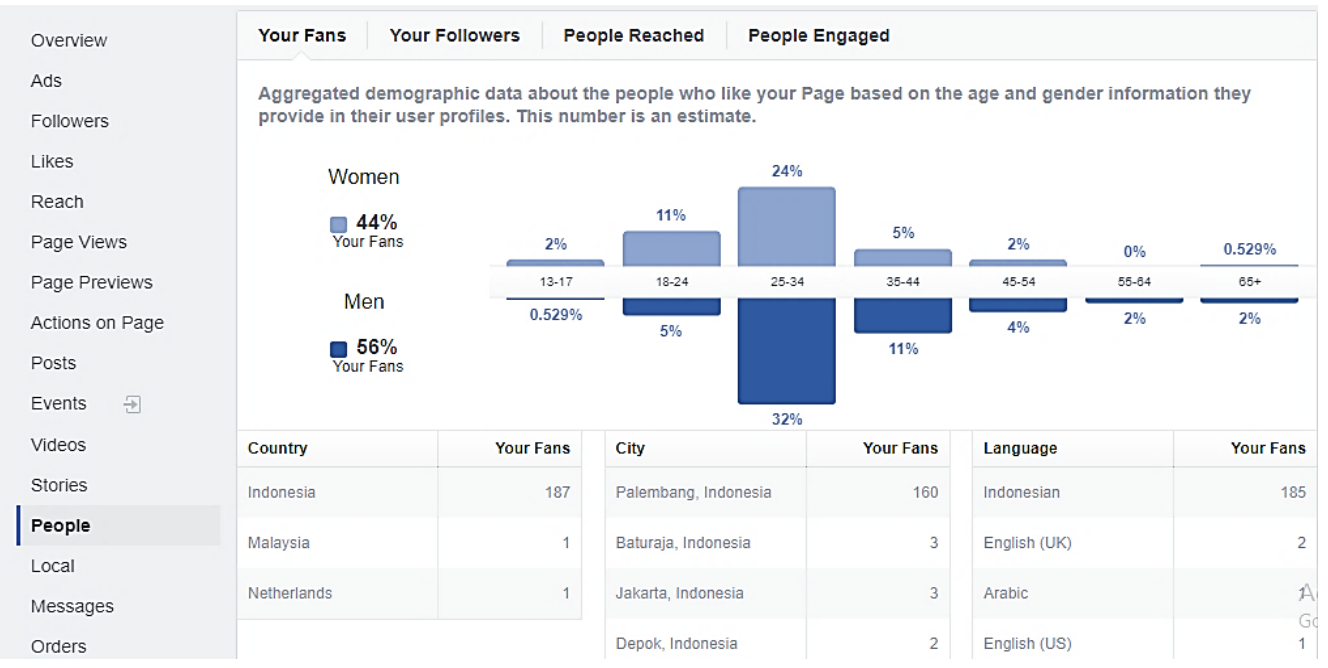

Figure 5. Information analysis on Facebook

Analysis of information dissemination was done through Semambu island social media, which was on Facebook page with users who liked the page as many as 189 people or $11.05 \%$ of the total reached customers and follow it as many as 192 people or $11.23 \%$. Meanwhile, those who interact with the page were 114 people or $6.67 \%$. It was known that the most preferred type of information was videos, then photos and links. The right time to share information was from 5:00 to 6:00 in the morning, 19:00 in the evening and 22:00 to 23:00 at night. Meanwhile the analysis on Instagram showed that the followers of Semambu island were as many as 709 people consisting of $48 \%$ men and $52 \%$ women. The majority of followers came from Palembang city and the best time to spread information through Instagram was around 12:00 noon except Friday which was at around 14.00 afternoon.

Through the system, customer information can be stored by tour managers from the customer booking process through the website and can be accessed in real time from Facebook and Instagram, in the form of responses and interactions of social media users with the page and on Semambu island tourism village social media accounts. Travel information can be managed by the website-based system with an attractive and well-packed look rather than using only limited social media. The data was owned entirely by the developer and it increased customer confidence in the seriousness of the management team in managing Semambu island tourism village to aquire new customers. Enhancing customer value was done by offering other complementary products and services from Semambu island village and the product from the village community through appropriate promotion by segmentation of social media users who were interested or less interested based on their responses of social media. Then retaining customers was done by listening to what they wanted through complains, suggestions and communicating personally to each customer through their email and social media. 


\section{CONCLUSION}

This research concludes that the management using social media just for share information without any purpose to get more advantage of social media, so this research builds web base CRM and connecting to social media Facebook and Instagram. The dissemination of tourism information is more effective using social media because it can determine promotion targets, find out their interests and communicate with each customer. CRM and social media integration make managing and disseminating information efficient. Acquire, enhance and retaining customer trough social CRM can be done more varied with many facilities in social media. This research gets information about who are the potential customer, where are them from, their age and gender based on the amount of users that interest and interact with the tourism information at social media. For the future research, it can be use more advantage of social media fitur that provide and combine it with CRM strategy to build better social CRM.

\section{ACKNOWLEDGEMENTS}

This research received no specific grant from any funding agency in the public, commercial, or notfor profit sectors. But we would like to thank Semambu island tourism village for the permission to do this research and willingness to share their information.

\section{REFERENCES}

[1] H. Al-Rubaiee, K. Alomar, R. Qiu, and D. Li, "Tuning of Customer Relationship Management (CRM) via Customer Experience Management (CEM) using Sentiment Analysis on Aspects Level," Int. J. Adv. Compt. Scie.e Apps., vol. 9, no. 5, pp. 300-312, 2018, doi: 10.14569/IJACSA.2018.090540.

[2] M. Randika, N. A. Andestra, S. Inayah, D. M. Sari, A. R. Jannah and A. I., "Analysis of Line Application Deployment Using Customer Relationship Management Approach to Customer Loyalty in GO-US," in Proc. Sriwijaya Int. Conf. Inf. Tech. Apps., vol. 172, 2019, pp. 674-679, doi: 10.2991/aisr.k.200424.102.

[3] M. F. Aldaihani and N. Azman, "Impact of Social Customer Relationship Management on Customer Satisfaction through Customer Empowerment: A Study of Islamic Banks in Kuwait," International Research Journal of Finance and Economics, vol. 170, no. 170, pp. 41-53, 2018.

[4] P. Meyliana, A. N. Hidayanto, and E. K. Budiardjo, "Social Media Adoption for Social CRM in Higher Education: An Insight from Indonesian Universities," International Journal of Synergy and Research, vol. 4, no. 2, pp. 7-28, 2019. doi: 10.17951/ijsr.2015.4.2.7.

[5] E. C. Malthouse, M. Haenlein, B. Skiera, E. Wege, and M. Zhang, "Managing Customer Relationship in Social Media Era: Introducing the Social CRM House,” Journal of Internet Marketing, vol. 27, no.4, pp. 270-280, 2013, doi: 10.1016/j.intmar.2013.09.008

[6] M. Kubina and V. Lendel, "Successfull Application of Social CRM in the Company," Procedia Economics and Finance, vol. 23, pp. 1990-1994, 2015, doi: 10.1016/S2212-5671(15)00487-6.

[7] K. Paliouraus and K. V. Siakas, "Social Customer Relationship Management: A Case Study," International Journal of Entrepreneurial Knowledge, vol. 5, no. 1, pp. 20-34, 2017, doi: 10.1515/ijek-2017-0002.

[8] C. A. Elena, "Social Media-A Strategy in Developing Customer Relationship Management," Procedia Economics and Finance, vol. 39, pp. 785-790, 2015, doi: 10.1016/S2212-5671(16)30266-0.

[9] A. Ibrahim, Ermatita, Saparudin, and Z. Adetya, "Analysis of weakness of data validation from social CRM," 2017 Int. Conf. Data and Soft. Eng. (ICoDSE), 2017, pp. 1-5, doi: 10.1109/ICODSE.2017.8285849.

[10] S. San-Martin, N. H. Jimenez, and B. Lopez-Catalan, "The Firms Benefits of Mobile CRM from the Relationship Marketing Approach and the TOE Model," Spanish Journal of Marketing - ESIC, vol. 20, no. 1, pp. 18-29, 2016. doi: 10.1016/j.reimke.2015.07.001.

[11] S. Diffley and P. McCole, "Extending Customer Relationship Management into a Social Context," Service Industries Journal, vol. 35, no. 11-12, pp. 591-610, 2015, doi: 10.1080/02642069.2015.1062882.

[12] A. Ibrahim and S. Amatullah, "Implementing Customer Relationship Management to Increase Education Service using Service Quality Method," Journal of Information Systems Engineering and Business Intelligence, vol. 4, no. 2, pp. 148-155, 2018, doi: 10.20473/jisebi.4.2.148-155.

[13] P. Harrigan, U. Evers M. P. Miles, and T. M. Daly, "Customer Engagement with Tourism Social Media Brands," Tourism Management Journal, vol. 59, pp. 597-609, 2017, doi: 10.1016/j.tourman.2016.09.015.

[14] L. M. Lekhanya, "The Use of Social Media and Social Networks as the Promotional Tool for Rural Small, Medium and Micro Enterprises in KwaZulu-Natal," Int. J. Scien. Res. Pub., vol. 3, no. 7, 2013.

[15] M. Anshari, M. N. Almunawar, S. A. Lim and A. Al-Mudimigh, "Customer Relationship Management and Big Data Enabled: Personalization \& Customization of Services," Applied Computing and Informatics Journal, vol. 15, no. 2, pp. 94-101, 2018, doi: 10.1016/j.aci.2018.05.004.

[16] M. Sigala, "Implementing Social Customer Relationship Management a Process Framework and Implication in Tourism and Hospitality," International Journal of Contemporary Hospitality Management, vol.30, no.3, pp. 26982726, 2018, doi: 10.1108/IJCHM-10-2015-0536.

[17] A. Ibrahim, A. Alzaini, A. Wiranata, A. J. H. Sabrina, I. Dwazar, and R. R. Saputra, "Implementation of Quick Response to Customer Relationship Management System Based on Mobile Application," Sriwijaya International Conference on Information Technology and Its Applications, 2020, pp. 382-385, doi: 10.2991/aisr.k.200424.058. 
[18] K. F. Hashim and N. A. Fadhil, "Engaging with Customer Using Social Media Platform: Case study of Malaysia Hotels," Procedia Computer Science, vol. 124, pp. 4-11, 2017, doi: 10.1016/j.procs.2017.12.123.

[19] A. Ibrahim et al., "Implementation of Social Customer Relationship Management Using Instagram and Facebook as Songket Marketing Media," Sriwijaya International Conference on Information Technology and Its Applications (SICONIAN 2019), 2020, pp. 554-560, doi: 10.2991/aisr.k.200424.085.

[20] A. Ibrahim, A. Pratiwi, D. I. Meytri, Madri, M. A. Kurniawan, and N. Yuniarti, "Measuring Customer Satisfaction Using CRM Scorecard in Canteen FASILKOM UNSRI," 2018 International Conference on Electrical Engineering and Computer Science (ICECOS), 2018, pp. 403-408, doi: 10.1109/ICECOS.2018.8605253.

[21] Y. Zhao, L. Wang, and N. Gao, "The Improvement of CRM in Social Networking: A Case Study of Alibaba \& Sina," Int. Conf. Edu., Manag. Compt. Tech. (ICEMCT), 2015, pp. 216-220, doi: 10.2991/icemct-15.2015.46.

[22] Z. Wang and H. G. Kim, "Can Social Media Marketing Improve Customer Relationship Capabilities and Firm Performance? Dynamic Capability Perspective," Journal of Interactive Marketing, vol. 39, pp. 15-26, 2017, doi: 10.1016/j.intmar.2017.02.004.

[23] O. Reinhold and R. Alt, "Analytical Social CRM: Concept and Tool Support," 24 ${ }^{\text {th }}$ Bled Proceedings, 2011, pp. 226-241.

[24] M. Shanmugam, V. Karunakaran, and A. Amidi, "Formulation of an integrated social commerce framework to promote social capital for energy sectors," Indonesian Journal of Electrical Engineering and Computer Science, vol. 15, no. 1, pp. 427-434, 2019, doi: 1 0.11591/ijeecs.v15.i1.pp427-434.

[25] N. Woodcock, A. Green, and M. Starkey, "Social CRM as a Business Strategy," Journal of Database Marketing and Customer Strategy Management, vol. 18, pp. 50-64, 2011, doi: 10.1057/dbm.2011.7.

[26] M. Marolt, A. Pucihar, and H. Zimmermann, "Social CRM Adoption and Its Impact on Performance Outcomes: A Literature Review," Organizacija Journal, vol. 48, no.4, pp. 260-271, 2015, doi: 10.1515/orga-2015-0022.

[27] M. Nadeem, "Social Customer Relationship Management (SCRM): How Connecting Social Analytics to Business Analytics Enhances Customer Care and Loyalty?,"Int. J. Bus. and Soc. Sci. vol. 3, no. 21, pp. 88-102, 2012.

[28] K. S. Bayne and B. A. Cianfrone, "The Effectiveness of Social Media Marketing: The Impact of Facebook Status Updates on a Campus Recreation Event," Recreational Sports Journal, vol 37, no. 2, pp. 147-159, 2013, doi: 10.1123/rsj.37.2.147.

[29] A. Mazzucchelli, R. Chierici, F. Ceruti, and A. D. Gregorio, "Strengthening Customer Relationship in the Social Media Era: The Importance of Customer Relationship Orientation and Customer Knowledge Management," International Journal of Business and Social Science, vol 8, no. 10, pp. 186-194, 2017.

[30] S. Sarkum, B. A. Pramuka and A. Suroso, "The Integration Paradigm of Social CRM," International Journal of Recent Scientific Research, vol. 8, no. 7, pp. 18054-18058, 2017, doi: 10.24327/ijrsr.2017.0807.0442.

[31] N. C. Valentin, N. Oana, G. Adriana, and C. Elena, "Exploratory Study of the Companies' Economic Performance Using a Social Customer Relationship Management." Procedia Economics and Finance, vol. 39, pp. 800-806, 2016, doi: 10.1016/S2212-5671(16)30270-2.

[32] N. A. N. M. Idros, H. Mohamed, and R. Jenal, "The use of expert review in component development for customer satisfaction towards E-hailing," Indonesian Journal of Electrical Engineering and Computer Science, vol. 17, no. 1, pp. 347-356, 2019, doi: 10.11591/ijeecs.v17.i1.pp347-356.

[33] T. Chung, N. A. Ananza, P. Joohyung, and A. Hall-Phillip, "Who's behind the screen? Segmenting Social Venture Consumers through Social Media Usage," Journal of Retailing and Consumer Services, vol. 28, pp. 288-295, 2015, doi: 10.1016/j.jretconser.2015.01.006.

[34] C. Kaewphet and N. Wisitpongpun, "Algorithm for extracting product feature from e-commerce comment," Indonesian Journal of Electrical Engineering and Computer Science, vol. 22, no. 2, pp. 1199-1207, 2021, doi: 10.11591/ijeecs.v22.i2.pp1199-1207.

[35] J. Xu, J. Wei, and D. Zhao, "Influence of Social Media on Operational Efficiency of National Scenic Spots in China Based on Three-Stage DEA Model," International Journal of Information Management, vol. 36, no.3, pp. 374-388, 2016, doi: 10.1016/j.ijinfomgt.2016.01.002.

[36] A. Daghouri, K. Mansouri, and M. Qbadou, "The impact of IT investment on firm performance based on MCDM techniques," International Journal of Electrical and Computer Engineering, vol. 9, no. 5, pp. 4344-4354, 2019, doi: 10.11591/ijece.v9i5.pp4344-4354.

[37] N. S. Shaeeali, A. Mohamed, and S. Mutalib, "Customer reviews analytics on food delivery services in social media: A review," IAES International Journal of Artificial Intelligence, vol. 9, no. 4, pp. 691-699, 2020, doi: 10.11591/ijai.v9.i4.pp691-699.

[38] V. Kasinathan, A. Mustapha, M. F. C. A. Rani, and S. A. Mostafa, "The role of chatterbots in enhancing tourism: A case study of Penang tourism spots," IAES International Journal of Artificial Intelligence, vol. 9, no. 4, pp. 569-575, 2020, doi: 10.11591/ijai.v9.i4.pp569-575.

[39] H. A. Riyadh, S. A. Alfaiza, A. A. Sultan, M. K. Faaeq, and R. Dananjoyo, "An analysis of CRM practices in the telecommunication industry in Iraq," Indonesian Journal of Electrical Engineering and Computer Science, vol. 23, no. 1, pp. 453-462, 2021, doi: 10.11591/ijeecs.v23.i1.pp453-462.

[40] R. A. Ojelabi, A. O. Afolabi, O. O. Oyeyipo, P. F. Tunji-Olayeni, and B. A. Adewale, "Data Exploration of Social Client Relationship Management (CRM 2.0) Adoption in the Nigerian Construction Business," Data in Brief Journal, pp. 1471-1476, 2018, doi: 10.1016/j.dib.2018.04.037.

[41] K. Kallio, "The Effectiveness of Using Social Media as A Marketing Communication Tactic, Case Gina Tricot Ltd," Thesis, Department of Business Economics, Vaasa University of Applied Sciences, Vaasa, Findland, 2015.

[42] M. S. Farhan, A. H. Abed, and M. A. Ellatif, "A Systematic Review for the Determination and Classification of The CRM Critical Success Factors Supporting with Their Metrics," Future Computing and Informatics Journal, vol. 3, no. 2, pp. 398-416, 2018, doi: 10.1016/j.fcij.2018.11.003. 
[43] S. Guha, P. Harrigan, and G. Soutar, "Linking Social Media to Customer Relationship Management (CRM): A Qualitative study on SMEs," Journal of Small Business \& Entrepreneurship, vol. 30, no. 3, pp. 193-214, 2017, doi: 10.1080/08276331.2017.1399628.

[44] I. Almarashdeh, "The effect of recovery satisfaction on citizens loyalty perception: A case study of mobile government services," International Journal of Electrical and Computer Engineering, vol. 10, no. 4, pp. 42794295, 2020, doi: 10.11591/ijece.v10i4.pp4279-4295.

[45] N. Wittkuhn, T. Lehmkuh, T. Kupper, and R. Jung, "Social CRM Performance Dimensions: A Resource-based View and Dynamic Capabilities Perspective," 28th Bled Proceedings, 2015.

[46] T. Kuepper, T. Eymann, R. Jung, T. Lehmkuhl, S. Walther, and A. Wieneke, "Measuring Social CRM Performance: A Preliminary Measurement Model,"Wirtschaftsinformatik Proceedings, 2015, pp. 887-901.

[47] A. Dennis, B. Wixon, and R. M. Roth, System Analysis \& Design, New York, USA: John Wiley \& Sons, 2012.

[48] U. A. Patel and N. K. Jain, "New Idea in Waterfall Model for Real Time Software Development." International Journal of Engineering Research \& Technology, vol. 2, no. 4, pp. 114-119, 2013.

[49] O. Somantri and D. Apriliani, "Opinion mining on culinary food customer satisfaction using naïve bayes based-on hybrid feature selection," Indonesian Journal of Electrical Engineering and Computer Science, vol. 15, no. 1, pp. 468-475, 2019, doi: 10.11591/ijeecs.v15.i1.pp468-475.

[50] H. Syafitri and A. Ibrahim, "Performance Measuring Analysis of Customer Relationship Management MyXL Using CRM-Scorecard," in Proceedings of the Sriwijaya International Conference on Information Technology and Its Applications (SICONIAN 2019), vol. 172, 2019, pp. 155-166, doi: 10.2991/aisr.k.200424.023.

\section{BIOGRAPHIES OF AUTHORS}
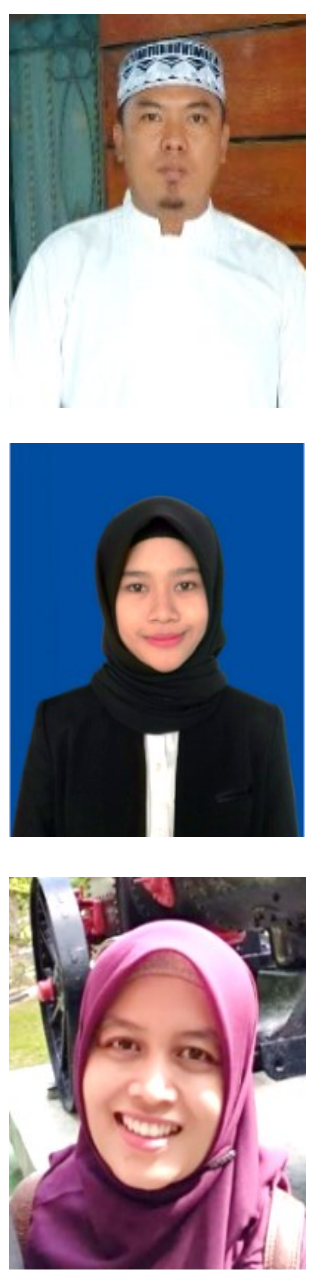

Ali Ibrahim is a Lecturer in Department of Information Systems Faculty of Computer Science, Universitas Sriwijaya, Indonesia. He is currently a part of Management of Information Systems and Business (MISaB) Research Group, Faculty of Computer Science Universitas Sriwijaya, Indonesia. Multimedia and Game Programming Laboratory Faculty of Computer Science Universitas Sriwijaya, Indonesia. Can be contact via email aliibrahimok@gmail.com, aliibrahim@unsri.ac.id or aliibrahim@ilkom.unsri.ac.id.

Devi Indra Meytri is an alumnus of Department of Information Systems Faculty of Computer Science, Universitas Sriwijaya, Indonesia. She can be contact via email indrameytri@gmail.com.

Dwi Rosa Indah is a Lecturer in Department of Information Systems Faculty of Computer Science, Universitas Sriwijaya, Indonesia and a part of Data structures and accounting information systems Laboratory Faculty of Computer Science Universitas Sriwijaya, Indonesia. Can be contact via email indah812@gmail.com 